\title{
Hydrogen peroxide-responsive AIE probe for imaging-guided organelle targeting and photodynamic cancer cell ablation
}

Qian Wu, ${ }^{a, b}$ Youmei Li, ${ }^{a, b}$ Ying Li, ${ }^{* a}$ Dong Wang ${ }^{\star a}$ and Ben Zhong Tang ${ }^{* c, d}$

${ }^{a}$ Center for AIE Research, Shenzhen Key Laboratory of Polymer Science and Technology, Guangdong Research Center for Interfacial Engineering of Functional Materials, College of Materials Science and Engineering, Shenzhen University, Shenzhen 518061 (P. R. China). E-mail: wangd@szu.edu.cn.

${ }^{b}$ Key Laboratory of Optoelectronic Devices and Systems of Ministry of Education and Guangdong Province, College of Optoelectronic Engineering, Shenzhen University, Shenzhen, 518060, China.

${ }^{c}$ Department of Chemistry, Hong Kong Branch of Chinese National Engineering Research Center for Tissue Restoration and Reconstruction, The Hong Kong University of Science and Technology, Clear Water Bay, Kowloon, Hong Kong, 999077, China.

E-mail: tangbenz@ust.hk.

${ }^{d}$ NSFC Center for Luminescence from Molecular Aggregates, SCUT-HKUST Joint Research Institute, State Key Laboratory of Luminescent Materials and Devices, South China University of Technology, Guangzhou 510640, China.

Abstract: Hydrogen peroxide $\left(\mathrm{H}_{2} \mathrm{O}_{2}\right)$, as one kind of key reactive oxygen species (ROS), is mainly produced endogenously primarily in the mitochondria. The selective monitoring of $\mathrm{H}_{2} \mathrm{O}_{2}$ in living cells is of great significance for understanding diagnosis and pathogenesis of cancers, the Alzheimer's disease and diabetes. Here, we constructed a versatile AIE probe, TTPy $-\mathrm{H}_{2} \mathrm{O}_{2}$, which achieved superb performances in the specifically visualization of $\mathrm{H}_{2} \mathrm{O}_{2}$ specifically in various living cells with mitochondria targeting, excellent biocompatibility and photostability, and remarkable ROS generation ability. Red/near-infrared fluorescence firstly located in the mitochondria could light up lipid droplets with bright yellow fluorescence after responding to the $\mathrm{H}_{2} \mathrm{O}_{2}$, which can realize both imaging and photodynamic therapy (PDT) for cancer therapy.

\section{Introduction}

Reactive oxygen species (ROS), mainly including singlet oxygen $\left({ }^{1} \mathrm{O}_{2}\right)$, superoxide anion $\left(\mathrm{O}_{2}{ }^{-}\right)$, hydrogen peroxide $\left(\mathrm{H}_{2} \mathrm{O}_{2}\right)$, and hydroxyl radical $(\mathrm{HO} \cdot)$, are produced endogenously as by-products of cellular metabolism primarily in the mitochondria, and serve as indispensable messengers involving in multiple physiological processes. ${ }^{1-6} \mathrm{H}_{2} \mathrm{O}_{2}$, as a kind of representative ROS, has received growing concern by the virtue of its oxidative damage of biomacromolecules such as proteins, liposomes and DNA when overproduced or excessively accumulated. Increasing evidence indicates that the unbalance of $\mathrm{H}_{2} \mathrm{O}_{2}$ homeostasis is related to various human diseases including cancers, the Alzheimer's disease, diabetes, and aging. ${ }^{7-11}$ Specifically, it may estimate that there is much higher concentration of $\mathrm{H}_{2} \mathrm{O}_{2}$ in cancer cells (10$100 \mu \mathrm{M})$ than those in normal cells $(0.001-0.7 \mu \mathrm{M}) .{ }^{12-14}$ As a consequence, it is of great significance to develop novel imaging methods which allow real-time monitoring of the level of $\mathrm{H}_{2} \mathrm{O}_{2}$ in the living cells, and provide instructive guidance for the diagnosis and further therapy of cancers.

In the past decades, fluorescence imaging has been regarded as one of the most promising imaging methods in living system on account of its distinctive advantages including non-invasiveness, high-sensitivity, and low-cost. A variety of organic fluorescence bioprobes have been designed and constructed for the selective detection of $\mathrm{H}_{2} \mathrm{O}_{2}$ in the living cells. ${ }^{15-21}$ Thereinto, fluorogens with aggregation-induced emission (AIE) characteristics have arisen as a novel family of 
fluorescence imaging materials and enjoyed omnipotent applications in bioimaging, biosensing and therapeutics. ${ }^{22-24}$ They usually possess the unique superiorities of modifiable structure, large Stokes-shift, low background, and good stability against photobleaching, which endows them with great potentials in real-time monitoring of bioactive molecules like $\mathrm{H}_{2} \mathrm{O}_{2}$ in living system. ${ }^{25-28}$

To date, several works have been reported to implement a "turn-on" fluorescence by utilizing AIE bioprobe to selectively react with $\mathrm{H}_{2} \mathrm{O}_{2}$ and achieve aggregation-induced emission in cytoplasm or specific organelles. ${ }^{29-32}$ Moreover, reasonable regulation of energy in the excited state enables AIE bioprobe to image $\mathrm{H}_{2} \mathrm{O}_{2}$ in living cells and simultaneously ablate cancer cells by photodynamic therapy (PDT) and photothermal therapy (PTT). ${ }^{33,34}$ However, rare research has focus on the real-time monitoring of $\mathrm{H}_{2} \mathrm{O}_{2}$ and visualizing dynamic change of organelles, especially for the mitochondria, in the process of PDT.

In view of the above situation, here we designed and constructed a $\mathrm{H}_{2} \mathrm{O}_{2}$-responsive AlE probe for targeted organelle imaging and PDT of cancer cells for the first time. As shown in Scheme 1, a versatile fluorescent probe termed as TTPy- $\mathrm{H}_{2} \mathrm{O}_{2}$ was ingeniously designed on the basis of the following considerations. Firstly, p-pinacolborylbenzyl moiety was adopted as reaction unit on account of its unique reactivity with $\mathrm{H}_{2} \mathrm{O}_{2}$ which has been demonstrated in the previous work. ${ }^{16,35}$ Then pyridinium cation was introduced to allow specifically targeting mitochondria by the electrostatic interaction with electronegative mitochondrial membrane. ${ }^{36,37}$ More importantly, it was also utilized as strong electron acceptor and linked to triphenylamine-thiophene building block, constructing a twisted donor-acceptor (D-A) structure which will facilitate the red-shift of emission wavelength and large Stokes shift. Besides, the multiple freely rotatable phenyl groups and double bond were beneficial to quenching fluorescence in the solution while endowing strong aggregation-induced emission in the targeted organelles. ${ }^{38,39}$ According to our preliminary study, this strong D-A structure showed great potential to be a good photosensitizer for PDT. ${ }^{40-42}$ As expected, the AIE probe TTPy- $\mathrm{H}_{2} \mathrm{O}_{2}$ with red/near-infrared (NIR) emission and moderate water solubility firstly lighted up mitochondria specifically in living cells. After reacting with overproduced $\mathrm{H}_{2} \mathrm{O}_{2}$ primarily in the mitochondria of cancer cells, TTPy- $\mathrm{H}_{2} \mathrm{O}_{2}$ was transformed to be

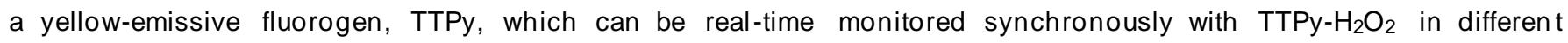
channels of confocal laser scanning microscope (CLSM). Interestingly, hydrophobic TTPy was observed to easily transfer into lipid droplets (LD). Hence, our AIE probe TTPy- $\mathrm{H}_{2} \mathrm{O}_{2}$ with mitochondria targeting can make a selectively response to $\mathrm{H}_{2} \mathrm{O}_{2}$ in living cells. The synchronous changes of fluorescence wavelength and the organelle targeting can serve as an indicator for the further PDT on cancer cells. In addition, this $\mathrm{H}_{2} \mathrm{O}_{2}$ responsive and dual signals read-out can indicate the performance of PDT in living cells to demonstrate the efficient generation of singlet oxygen and effective ablation of cancer cells. The dynamic change of mitochondria in the process of PDT can be monitored in real-time, which provides a novel insight to investigate the damage mechanism of ROS in living system and the related diseases.

\section{Experimental section}




\section{Materials and instruments}

All the chemicals and biological reagents for synthesis and analysis were purchased from Energy, Bide and SigmaAldrich Chemical Reagent Ltd., and used without further purification unless specified requirement. Nuclear magnetic resonance (NMR) spectra were measured on Bruker AVANCE III 400MHZ and 500MHZ NMR spectrometers. High resolution mass spectrometer (HRMS) was tested on Thermo Exactive Focus Q. UV-vis absorption spectra were measured on a PerkinElmer Lambda 950 spectrophotometer. Fluorescence spectra were recorded on Edinburgh FS5 fluorescence spectrophotometer. Quantum yield was determined by a Quanta-integrating sphere. Fluorescence images were collected on a confocal laser scanning microscope (CLSM, ZEISS-LSM900) and analyzed by using ZEN 3.2 software. The 3-(4,5-dimethyl-2-thiazolyl)-2,5-diphenyl-2- $H$-tetrazolium bromide (MTT) assay was conducted on a BioTek microplate reader.

\section{Synthesis of $\mathrm{TTPy}-\mathrm{H}_{2} \mathrm{O}_{2}$}

4-Bromomethylphenylboronic acid pinacolester (150 mg, $0.5 \mathrm{mmol})$ and TTPy (215 $\mathrm{mg}, 0.5 \mathrm{mmol})$ were refluxed under nitrogen in dry acetonitrile $(10 \mathrm{~mL})$ at $80^{\circ} \mathrm{C}$ for $8 \mathrm{~h}$. After cooling to room temperature, the mixture was added into 50 $\mathrm{mL}$ of ice-cooled diethyl ether with vigorous stirring. The precipitates were separated by centrifugation and washed three times with diethyl ether and dried in a vacuum at $40{ }^{\circ} \mathrm{C}$ to a constant weight. Eventually, $\mathrm{TTPy}-\mathrm{H}_{2} \mathrm{O}_{2}$ was obtained as deep red powder in $88 \%$ yield $(320 \mathrm{mg}) .{ }^{1} \mathrm{H}$ NMR $\left(400 \mathrm{MHz}, \mathrm{CD}_{2} \mathrm{Cl}_{2}\right) \delta 9.08(\mathrm{~d}, \mathrm{~J}=6.6 \mathrm{~Hz}, 2 \mathrm{H}), 8.00(\mathrm{~d}, J=15.7 \mathrm{~Hz}$, $1 \mathrm{H}), 7.92(\mathrm{~d}, J=6.6 \mathrm{~Hz}, 2 \mathrm{H}), 7.78(\mathrm{~d}, J=8.0 \mathrm{~Hz}, 2 \mathrm{H}), 7.56(\mathrm{~d}, J=8.1 \mathrm{~Hz}, 2 \mathrm{H}), 7.46-7.40(\mathrm{~m}, 3 \mathrm{H}), 7.28(\mathrm{dd}, J=8.8$, $7.1 \mathrm{~Hz}, 4 \mathrm{H}), 7.17(\mathrm{~d}, J=3.9 \mathrm{~Hz}, 1 \mathrm{H}), 7.08(\mathrm{~d}, J=7.5 \mathrm{~Hz}, 6 \mathrm{H}), 6.99(\mathrm{~d}, J=8.8 \mathrm{~Hz}, 2 \mathrm{H}), 6.75(\mathrm{~d}, J=15.8 \mathrm{~Hz}, 1 \mathrm{H}), 6.05$ (s, 2H), 1.30 (s, 12H). ${ }^{13} \mathrm{C} \operatorname{NMR}\left(101 \mathrm{MHz}, \mathrm{CD}_{2} \mathrm{Cl}_{2}\right) \delta 154.06,149.92,149.09,147.59,144.37,139.11,136.84,136.16$, $135.88,135.28,129.97,129.00,127.34,127.06,125.61,124.29,124.07,123.88,122.94,120.38,84.61,63.37,25.19$. HRMS: calcd. for $\left[\mathrm{C}_{42} \mathrm{H}_{40} \mathrm{BN}_{2} \mathrm{O}_{2} \mathrm{~S}\right]^{+}:$: 647.2898, found 647.2922 .

\section{Results and discussion}

\section{Molecular synthesis of TTPy- $\mathrm{H}_{2} \mathrm{O}_{2}$}

As shown in experimental section and supplementary information, TTPy $-\mathrm{H}_{2} \mathrm{O}_{2}$ was facilely obtained by a two-step synthetic route. Triphenylamine-thiophene building block containing active aldehyde group was condensed by reacting with 4-methylpyridine in the present of acid to directly afford TTPy which is the product in response of $\mathrm{H}_{2} \mathrm{O}_{2}$. Then $p$ pinacolborylbenzyl moiety was incorporated into TTPy to get purified TTPy $-\mathrm{H}_{2} \mathrm{O}_{2}$ as deep red powder by recrystallization and filtration without complicated column chromatography. The structures of the desired products have been confirmed by NMR spectra (Fig. S1-S2 and S4-S5) and HRMS (Fig. S3 and S6).

\section{Studies on optical properties and selective response of $\mathrm{H}_{2} \mathrm{O}_{2}$}


First of all, we investigated the optical properties of $\mathrm{TTPy}-\mathrm{H}_{2} \mathrm{O}_{2}$ to confirm the AIE characteristics and feasibility of imaging by dual channels. The UV-Vis and fluorescence spectra were explored and showed large Stokes shift of TTPy $\mathrm{H}_{2} \mathrm{O}_{2}(180 \mathrm{~nm})$ and TTPy $(180 \mathrm{~nm})$. Exactly separated excitation and emission channels were expected to be adopted in the further imaging in living cells (Fig. 1a and 1b). As designed, TTPy $-\mathrm{H}_{2} \mathrm{O}_{2}$ presented negligible fluorescence when molecularly dispersed in the solution with low quantum yield $\left(Q Y_{\text {soln }}=0.8 \%\right.$ ), and showed remarkable red/NIR emission $(670 \mathrm{~nm})$ in the aggregated or solid state $\left(Q Y_{\text {solid }}=2.4 \%\right)$ (Table $\left.S 1\right)$. The fluorescence intensity was constantly monitored with increasing volume fraction of toluene in DMSO/Toluene solution system. Aggregation-induced fluorescence enhancement was revealed when the fraction of toluene was more than $80 \%$ (Fig. 1c and 1d). All these excellent optical properties will be conducive to the detection of $\mathrm{H}_{2} \mathrm{O}_{2}$ by fluorescence imaging.

Before the practice in living system, we carried out simulated reaction with $\mathrm{H}_{2} \mathrm{O}_{2}$ in the bottles to investigate the selectivity, reactivity and sensitivity of the presented AIE probe. The fluorescence intensity of TTPy- $\mathrm{H}_{2} \mathrm{O}_{2}(10 \mu \mathrm{M})$ reacted with $\mathrm{H}_{2} \mathrm{O}_{2}(100 \mu \mathrm{M})$ at different $\mathrm{pH}$ values (2-12) was measured. Almost no increase of fluorescence intensity was observed at low $\mathrm{pH}$ value, while sudden enhancement took place when the $\mathrm{pH}$ value was higher than 6.0 and the fluorescence intensity reached a plateau at about 10.0 (Fig. 1e). This phenomenon implicated that mild alkaline condition may be in favour of this reaction. $\mathrm{TTPy}-\mathrm{H}_{2} \mathrm{O}_{2}$ also showed good stability in various $\mathrm{pH}$ values with unchanged fluorescence intensity. ${ }^{1,2}$ After various considerations of reaction efficiency and physiological environment, we chose $\mathrm{pH}$ value of 7.4 in the DMSO/PBS buffer $(3: 7 \mathrm{v} / \mathrm{v})$ as the standard reaction condition.

In order to confirm the selectivity, TTPy- $\mathrm{H}_{2} \mathrm{O}_{2}$ was incubated with active molecules in the living system respectively, including $\mathrm{ROS}\left(\mathrm{OCl}^{-}, \mathrm{O}_{2}^{--}\right.$, TBHP and $\left.\cdot \mathrm{OH}\right)$, reactive nitrogen species (NO), reductive species (GSH, Vc), amino acids (Cys, Glu and $\mathrm{Arg}$ ) and vital metal ions $\left(\mathrm{Fe}^{3+}, \mathrm{Ca}^{2+}\right.$ and $\left.\mathrm{Mg}^{2+}\right)$. As shown in Fig. 1f, all the fluorescence intensity displayed negligible change except $\mathrm{H}_{2} \mathrm{O}_{2}$ which showed a remarkable 37.5-fold enhancement. This result provided powerful support for the selective monitoring of $\mathrm{H}_{2} \mathrm{O}_{2}$ in living cells without interference by other active molecules (Fig. 1f). Afterwards, the response time of TTPy $-\mathrm{H}_{2} \mathrm{O}_{2}(10 \mu \mathrm{M})$ in the presence or absence of $\mathrm{H}_{2} \mathrm{O}_{2}(100 \mu \mathrm{M})$ was studied. As displayed in Fig. 1 and $1 \mathrm{~g}$, there was almost no change of emission in the absence of $\mathrm{H}_{2} \mathrm{O}_{2}$, suggesting that the excellent stability of TTPy $-\mathrm{H}_{2} \mathrm{O}_{2}$ under the detection condition. Conversely, after adding $\mathrm{H}_{2} \mathrm{O}_{2}$, the fluorescence intensity at 590 $\mathrm{nm}$ was rapidly increased at the beginning and gradually reached the plateau around 50 minutes. The monitoring by liquid chromatography-mass spectrometry further elucidated that TTPy was generated from TTPy- $\mathrm{H}_{2} \mathrm{O}_{2}$. The titration experiment was conducted with different concentration of $\mathrm{H}_{2} \mathrm{O}_{2}$. The fluorescence intensity and the plot of peak intensity at $590 \mathrm{~nm}$ versus related concentration were exhibited in Fig. $1 \mathrm{~g}$ and $1 \mathrm{~h}$. A linear relationship in the range of 0 to $30 \mu \mathrm{M}$ was illustrated with the square of correlation coefficient equalling to 0.98 . Besides, the detection limit (LOD) of TTPy $\mathrm{H}_{2} \mathrm{O}_{2}$ towards $\mathrm{H}_{2} \mathrm{O}_{2}$ was estimated to be $0.25 \mu \mathrm{M}$ in terms of $3 \sigma / B$ formula ( $\sigma$ is the standard deviation of blank measurements, $\mathrm{n}=11$, and $B$ is the slope of the linear equation). Finally, the peak intensity reached a plateau at a concentration of $80 \mu \mathrm{M}$ which indicated the saturated concentration of this reaction (Fig. 1i and 1j). Above experimental 
results testified that TTPy $-\mathrm{H}_{2} \mathrm{O}_{2}$ was an excellent AIE bioprobe for the selective and sensitive detection of $\mathrm{H}_{2} \mathrm{O}_{2}$, by displaying the significant fluorescence change.

\section{Studies on capacity of ROS generation upon light irradiation}

For the purpose of killing of cancer cells by PDT, the capacity of $\mathrm{TTPy}-\mathrm{H}_{2} \mathrm{O}_{2}$ to generate ROS upon lightirradiation was studied by utilizing two different indicators. The increase of fluorescence intensity of dichlorofluorescin (DCFH) commonly indicated that the total content of all kinds of ROS, while the decrease of fluorescence intensity of 9,10 anthracenediyl-bis (methylene)-dimalonic acid (ABDA) specifically indicated the content of singlet oxygen $\left({ }^{1} \mathrm{O}_{2}\right)(\mathrm{Fig} .1 \mathrm{k}$ and 1I). Hence, rapid and considerable change in fluorescence intensity of DCFH and absorption intensity of ABDA suggested that TTPy- $\mathrm{H}_{2} \mathrm{O}_{2}$ can efficiently generate $\mathrm{ROS}$ containing various species upon white light irradiation. While the capacity of TTPy was slightly weaker to generate ROS mainly containing ${ }^{1} \mathrm{O}_{2}$. It was reasonable due to the weaker D-A interaction of TTPy.

\section{Investigation on the organelle targeting ability of TTPy- $\mathrm{H}_{2} \mathrm{O}_{2}$ before and after responding to $\mathrm{H}_{2} \mathrm{O}_{2}$}

Encouraged by above encouraging results, we made attempts to apply for the real-time detection of $\mathrm{H}_{2} \mathrm{O}_{2}$ in living cells. We investigated the organelle targeting ability of TTPy $-\mathrm{H}_{2} \mathrm{O}_{2}$ before and after responding to $\mathrm{H}_{2} \mathrm{O}_{2}$ using CLSM. Importantly, two separated imaging channels were screened for respectively monitoring the fluorescence in cells before and after responding to $\mathrm{H}_{2} \mathrm{O}_{2}$. The red channel for TTPy $-\mathrm{H}_{2} \mathrm{O}_{2}$ was used at the emission wavelength range from $650 \mathrm{~nm}$ to $700 \mathrm{~nm}(\lambda \mathrm{ex}=488 \mathrm{~nm})$, mean while, the yellow channel for TTPy was used at the emission wavelength range from $410 \mathrm{~nm}$ to $550 \mathrm{~nm}\left(\lambda_{\mathrm{ex}}=405 \mathrm{~nm}\right)$. The red fluorescence was clearly shown by incubating TTPy- $\mathrm{H}_{2} \mathrm{O}_{2}(5 \mu \mathrm{M})$ with HeLa cells for 30 min, which was well merged with the commercial MitoTracker Deep Red with a Person's colocalization coefficient of 0.89 (Fig. 2a). No fluorescence was observed in yellow channel. The colocalization study in Hep G2 cells and Lo2 cells further confirmed the resul ts (Fig. S9). After treating $\mathrm{H}_{2} \mathrm{O}_{2}$ $(50 \mu \mathrm{M})$ for $1 \mathrm{~h}$, the bright yellow fluorescence was emerged, which shared the good overlap with commercial lipid droplet (LD) Tracker Deep Red (Person's colocalization coefficient of 0.91) (Fig. 2b). These interestingly phenomena elucidate that TTPy- $\mathrm{H}_{2} \mathrm{O}_{2}$ was a mitochondria-targeting probe with red/NIR emission, and could specifically light up LD with bright yellow fluorescence by the selective response to $\mathrm{H}_{2} \mathrm{O}_{2}$ in living cells. Compared with commercial MitoTracker Green, TTPy- $\mathrm{H}_{2} \mathrm{O}_{2}$ exhibited better photostability with minor decrease of fluo rescence intensity, indicating a good prospect in real -time monitoring (Fig. 2c and S8).

Next, the cell viability was firstly evaluated using MTT assay in multiple cell lines (Fig 2d, S15 and S16). Without light irradiation, both TTPy- $\mathrm{H}_{2} \mathrm{O}_{2}$ and TTPy exhibited low cytotoxicity towards HeLa cells, HepG2 cells and Lo2 cells. The different concentrations of $\mathrm{H}_{2} \mathrm{O}_{2}$ were studied to ensure the non -toxic to cells under experimental conditions (Fig. S14). Upon white light irradiation, the cell viability gradually decreased along with increasing concentration of TTPy $-\mathrm{H}_{2} \mathrm{O}_{2}$ and irradiation time, even as low as $5 \%$. The cell viability of TTPy was slightly higher than those treated by $\mathrm{TTPy}-\mathrm{H}_{2} \mathrm{O}_{2}$, which was in agree with above results 
in Fig 1. These results indicated that both of TTPy $-\mathrm{H}_{2} \mathrm{O}_{2}$ and TTPy were suitable for imaging with good biocompatibility and PDT of cancer cells with efficient ROS generation ability.

\section{Fluorescence imaging of selective detection of $\mathrm{H}_{2} \mathrm{O}_{2}$ in living cells}

In order to explore real-time detection of $\mathrm{H}_{2} \mathrm{O}_{2}$ in cancer cells, we evaluated the responsiveness of TTPy- $\mathrm{H}_{2} \mathrm{O}_{2}$ by incubating with different concentration of $\mathrm{H}_{2} \mathrm{O}_{2}$. The CLSM imaging displayed clear filamentous morphology of the mitochondria with red fluorescence in HeLa cells. LD was already lighted up in the present of low concentration of $\mathrm{H}_{2} \mathrm{O}_{2}(25 \mu \mathrm{M})$, and became brighter along with increasing concentration (Fig. S10). When $\mathrm{H}_{2} \mathrm{O}_{2}(50 \mu \mathrm{M})$ was added, the fluorescence intensity in yellow channel was observed to gradually enhance at the different time points, and that in red channel decreased (Fig. 3). More and more LD were visualized. All these results suggested that TTPy was firstly produced around mitochondria by the reaction between $\mathrm{TTPy}-\mathrm{H}_{2} \mathrm{O}_{2}$ and $\mathrm{H}_{2} \mathrm{O}_{2}$, and might undergo entering into the LDs owing to its hydrophobic property.

The imaging with collaborative changes of fluorescence and targeting organelle was also examined by endogenous $\mathrm{H}_{2} \mathrm{O}_{2}$. It was proven that phorbol myristate acetate (PMA) can stimulate cells to produce $\mathrm{H}_{2} \mathrm{O}_{2}{ }^{43}$ Hence, we incubated HeLa cells with TTPy $-\mathrm{H}_{2} \mathrm{O}_{2}(5 \mu \mathrm{M})$ for $30 \mathrm{~min}$. Then PMA $(2 \mu \mathrm{g} / \mathrm{mL})$ was added to test the response of TTPy $-\mathrm{H}_{2} \mathrm{O}_{2}$ to endogenous $\mathrm{H}_{2} \mathrm{O}_{2}$. The yellow fluo rescence was clearly visualized in LD after 90 min of incubation, indicating that TTPy- $\mathrm{H}_{2} \mathrm{O}_{2}$ can sensitively respond to not only exogenous but also endogenous $\mathrm{H}_{2} \mathrm{O}_{2}$ in living cells (Fig. 4).

\section{Intracellular ROS detection and PDT of cancer cells}

With the explicit indications of the changes in fluorescence and targeting organelle, cancer cells were expected to be identi fied by our AIE probe, TTPy- $\mathrm{H}_{2} \mathrm{O}_{2}$. Afterwards, intracellular ROSgeneration ability of TTPy $-\mathrm{H}_{2} \mathrm{O}_{2}$ was investigated in HeLa cells utilizing 2',7'-dichlorodi-hydrofluorescein diacetrate (DCFH-DA) as a ROS fluorescence indicator. In the experiment, $\mathrm{H}_{2} \mathrm{O}_{2}$ was removed after incubating with TTPy- $\mathrm{H}_{2} \mathrm{O}_{2}$ for $1 \mathrm{~h}$ in HeLa cells. And DCFH-DA was added for imaging the intracellular ROS which were generated by both TTPy- $\mathrm{H}_{2} \mathrm{O}_{2}$ in the mitochondria and TTPy in the LD. This PDT strategy combining ROS-induced damages in two vital organelles was expected to be more efficient in killing the cancer cells. The CLSM of cells showed obvious green fluorescence upon $5 \mathrm{sec}$ laser irradiation, and the fluorescence was enhanced sharply along with increased irradiation time (Fig. S13). After laser irradiation for $100 \mathrm{sec}$, ROS-induced cell morphological changes including the destruction of cytoskeleton and the leaking of cyto sol were indicated by the fluo rescence of DCFH-DA, while the control cells with out TTPy- $\mathrm{H}_{2} \mathrm{O}_{2}$ staining showed almost no change (Fig. S12). More interestingly, the red fluorescence of TTPy $-\mathrm{H}_{2} \mathrm{O}_{2}$ maintained superb photostability, which can monitor the morphological change of mitochondria from intact filamentous structure to fragmented and fuzzy form during the irradiation period. ${ }^{44}$ The imaging in yellow channel of TTPy also indicated the growing level of $\mathrm{H}_{2} \mathrm{O}_{2}$ (Fig. $5 \mathrm{a}$ and $\left.5 \mathrm{~b}\right)$. All above messages suggested the outstanding performance of TTPy $-\mathrm{H}_{2} \mathrm{O}_{2}$ in ROS generation in living cells.

Moreover, live/dead cell staining assay was carried out to evaluate the PDT effect by using Calcein-AM (green colour for live cells)/propidium iodide (PI) (red colour for dead cells) staining. HeLa cells was incubated with TTPy $-\mathrm{H}_{2} \mathrm{O}_{2}(5 \mu \mathrm{M})$ for 30 min, 
followed the treatment by $50 \mu \mathrm{M} \mathrm{H}_{2} \mathrm{O}_{2}$ for $1 \mathrm{~h}$. The cells treated with (serve as experimental group) or without (serve as control group) light irradiation (20 min) were further cultured for $2 \mathrm{~h}$. The CLSM imaging was conducted after Calcein -AM/PI staining for $30 \mathrm{~min}$. As shown in Fig. 5c and 5d, strong green fluorescence of Calcein -AM was visible in the control group, indicating the good biocompatibility of TTPy $-\mathrm{H}_{2} \mathrm{O}_{2}$ and TTPy. Oppositely, bright red fluorescence of $\mathrm{PI}$ was detected in the experimental group, illustrating the marvelous effect of our strategy for controllable photoablation of cancer cells (Fig. S17). Overall, after responding to $\mathrm{H}_{2} \mathrm{O}_{2}$, this system was successfully showed PDT effects on the cancer cells.

\section{Conclusions}

In summary, TTPy- $\mathrm{H}_{2} \mathrm{O}_{2}$, as a versatile mitochondria-targeting probe, has been utilized for selective monitoring of $\mathrm{H}_{2} \mathrm{O}_{2}$ in living cells and PDT-induced ablation of cancer cells. This probe was constructed by elaborate molecular design and simple synthetic method, possessing distinct superiorities of aggregation-induced red/NIR emission, large Stokes-shift, good biocompatibility, and prominent ROS generation ability upon light irradiation. The red fluorescence of TTPy $-\mathrm{H}_{2} \mathrm{O}_{2}$ in mitochondria was observed to become bright yellow fluorescence which can specifically light up LD in living cells. This novel collaborative imaging of both mitochondria and LD has been applied for the efficient photodynamic therapy on cancer cells. Besides, the remarkable photostability of $\mathrm{TTPy}-\mathrm{H}_{2} \mathrm{O}_{2}$ enabled real-time monitoring of the morphological change of mitochondria in the process of PDT. This interesting strategy will provide a novel insight for developing realtime detection systems towards bioactive molecules in assistance of "always-on" AIE bioprobes.

\section{Conflicts of interest}

There are no conflicts to declare.

\section{Acknowledgements}

This work was partially supported by the Natural Science Foundation of China (21907068), the China Postdoctoral Science Foundation Grant (2019M653003). Science and Technology Plan of Shenzhen (JCYJ20200109110608167)

\section{Notes and references}

1 B. C. Dickinson and C. J. Chang, Nat. Chem. Biol., 2011, 7, 504-511.

2 P. D. Ray, B. W. Huang and Y. Tsuji, Cell. Signal., 2012, 24, 981-990.

3 P. H. G. M. Willems, R. Rossignol, C. E. J. Dieteren, M. P. Murphy and W. J. H. Koopman, Cell Metab., 2015, 22, $207-218$.

4 M. D. Brand, Free Radical Bio. Med., 2016, 100, 14-31.

5 H. Sies, Redox Biol., 2017, 11, 613-619.

6 J. M. Roscoe and C. S. Sevier, Cells 2020, 9, 2314.

7 T. P. Szatrowski and C. F. Nathan, Cancer Res., 1991, 51, 794-798.

8 C. Behl, J. B. Davis, R. Lesley and D. Schubert, Cell 1994, 77, 817-827. 
9 M. T. Lin and M. F. Beal, Nature 2006, 443, 787-795.

10 M. Giorgio, M. Trinei, E. Migliaccio and P. G. Pelicci, Nat. Rev. Mol. Cell Bio., 2007, 8, 722-728.

11 P. I. Moreira, C. Carvalho, X. Zhu, M. A. Smith and G. Perry, BBA - Mol. Basis Dis., 2010, 1802, 2-10.

12 J. R. Stone, Arch. Biochem. Biophys., 2004, 422, 119-124.

13 M. Lopez-Lazaro, Cancer Lett., 2007, 252, 1-8.

14 H. Hagen, P. Marzenell, E. Jentzsch, F. Wenz, M. R. Veldwijk and A. Mokhir, J. Med. Chem., 2012, 55, $924-934$.

15 B. C. Dickinson, C. Huynh and C.J. Chang, J. Am. Chem. Soc., 2010, 132, 5906-5915.

16 A. R. Lippert, G. C. V. De Bittner and C. J. Chang, Acc. Chem. Res., 2011, 44, 793-804.

17 X. Chen, X. Tian, I. Shin and J. Yoon, Chem. Soc. Rev., 2011, 40, 4783-4804.

18 J. Chan, S. C. Dodani and C. J. Chang, Nat. Chem., 2012, 4, 973-984.

19 J. Xu, Y. Zhang, H. Yu, X. Gao and S. Shao, Anal. Chem., 2016, 88, 1455-1461.

20 Z. Wu, M. Liu, Z. Liu and Y. Tian, J. Am. Chem. Soc., 2020, 142, 7532-7541.

21 G. Yang, Z. Liu, R. Zhang, X. Tian, J. Chen, G. Han, B. Liu, X. Han, Y. Fu, Z. Hu and Z. Zhang, Angew. Chem. Int. Ed., 2020, 59, 16154-16160.

22 J. Luo, Z. Xie, J. W. Y. Lam, L. Cheng, H. Chen, C. Qiu, H. S. Kwok, X. Zhan, Y. Liu, D. Zhu and B. Z. Tang, Chem. Commun., $2001,1740-1741$.

23 N. Song, Z. Zhang, P. Liu, Y.-W. Yang, L. Wang, D. Wang and B. Z. Tang, Adv. Mater., 2020, 32, 2004208.

24 T. Han, D. Yan, Q. Wu, N. Song, H. Zhang and D. Wang, Chin. J. Chem., 2020, 38, DOI: 10.1002/cjoc.202000520.

25 W. Xu, D. Wang and B. Z. Tang, Angew. Chem. Int. Ed., 2020, 59, DOI: 10.1002/anie.202005899.

26 Z. Zhang, W. Xu, M. Kang, H. Wen, H. Guo, P. Zhang, L. Xi, K. Li, L. Wang, D. Wang and B. Z. Tang, Adv. Mater., 2020, 32, 2003210.

27 M. Kang, Z. Zhang, N. Song, M. Li, P. Sun, X. Chen, D. Wang and B. Z. Tang, Aggregate, 2020, 1, 80-106.

28 W. Xu, D. Wang and B. Z. Tang, Angew. Chem. Int. Ed., 2020, 59, DOI: 10.1002/anie.202005899.

29 W. Zhang, W. Liu, P. Li, F. Huang, H. Wang and B. Tang, Anal. Chem., 2015, 87, 9825-9828.

30 Z. Song, R. T. Kwok, D. Ding, H. Nie, J. W. Lam, B. Liu and B. Z. Tang, Chem. Commun., 2016, 52, 10076-10079.

31 Y. Liu, J. Nie, J. Niu, F. Meng and W. Lin, Sci. Rep., 2017, 7, 7293.

32 X. Wang, Y. Huang, W. Lv, C. Li, W. Zeng, Y. Zhang and X. Feng, Anal. Meth., 2017, 9, 1872-1875.

33 G. Jiang, C. Li, X. Liu, Q. Chen, X. Li, X. Gu, P. Zhang, Q. Lai and J. Wang, Adv. Opt. Mater., 2020, 8, 2001119.

34 N. Yang, W. Xiao, X. Song, W. Wang and X. Dong, Nano-Micro Lett., 2020, 12, DOI: 10.1007/s40820-019-0347-0.

35 L. C. Lo and C. Y. Chu, Chem. Commun., 2003, 2728-2729.

36 H. Zhu, J. Fan, J. Du and X. Peng, Acc. Chem. Res., 2016, 49, 2115-2126.

37 W. Xu, M. M. S. Lee, J.-J. Nie, Z. Zhang, R. T. K. Kwok, J. W. Y. Lam, F.-J. Xu, D. Wang and B. Z. Tang, Angew. Chem. Int. Ed., 2020, 59, 9610-9616.

38 D. Wang, H. Su, R. T. K. Kwok, X. Hu, H. Zou, Q. Luo, Michelle M. S. Lee, W. Xu, J. W. Y. Lam and B. Z. Tang, Chem. Sci., 2018, 9, 3685-3693.

39 D. Wang, M. M. S. Lee, G. Shan, R. T. K. Kwok, J. W. Y. Lam, H. Su, Y. Cai and B. Z. Tang, Adv. Mater., 2018, $30,1802105$. 
40 Y.-Y. Huang, P. Mroz, T. Zhiyentayev, S. K. Sharma, T. Balasubramanian, C. Ruzie, M. Krayer, D. Fan, K. E. Borbas, E. Yang, H. L. Kee, C. Kirmaier, J. R. Diers, D. F. Bocian, D. Holten, J. S. Lindsey and M. R. Hamblin, J. Med. Chem., 2010, 53, 40184027.

41 S. Xu, Y. Duan and B. Liu, Adv. Mater., 2020, 32, 1903530.

42 G. Feng, G.-Q. Zhang and D. Ding, Chem. Soc. Rev., 2020, 49, 8179-8234.

43 E. Gallin and S. Green, Blood 1987, 70, 694-701.

44 S. Grandemange, S. Herzig and J. C. Martinou, Semin. Cancer Biol., 2009, 19, 50-56. 


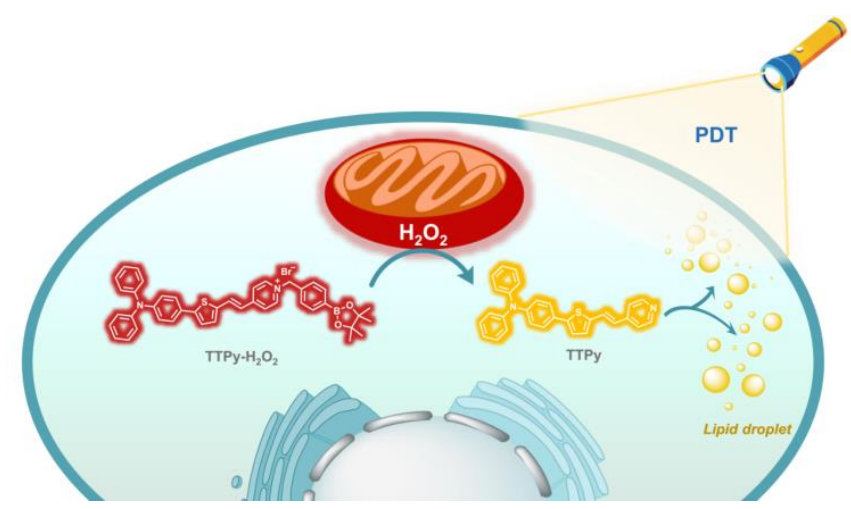

Scheme 1. Schematic illustration of $\mathrm{H}_{2} \mathrm{O}_{2}$ responsive AIE probe, TTPy- $\mathrm{H}_{2} \mathrm{O}_{2}$, with selective organelle-targeting for PDT on cancer cells.
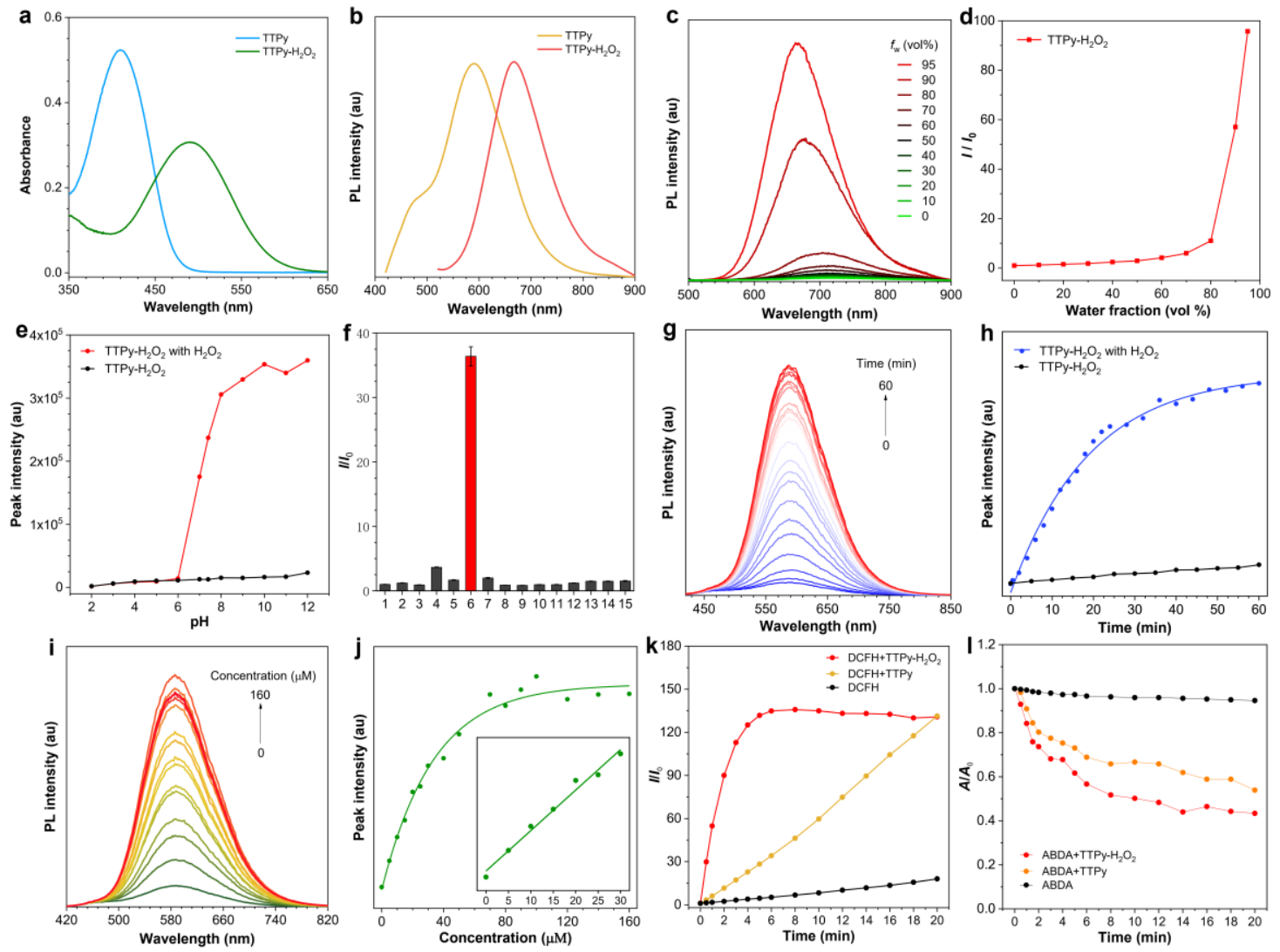

Figure 1. Characterization and $\mathrm{H}_{2} \mathrm{O}_{2}$ response. Absorption spectra (a) and $\mathrm{PL}$ spectra (b) of $T T P y-\mathrm{H}_{2} \mathrm{O}_{2}$ and $T \mathrm{PPy}(10 \mu \mathrm{M})$ in DMSO/PBS buffer $\left(3: 7 \mathrm{v} / \mathrm{v}, \mathrm{pH}\right.$ 7.4); (c) PL spectra of $T \mathrm{TPy}-\mathrm{H}_{2} \mathrm{O}_{2}(10 \mu \mathrm{M})$ in DMSO/Toluene mixtures with different toluene fractions $\left(f_{\mathrm{w}}\right) ; \lambda_{\mathrm{ex}}=500 \mathrm{~nm} ;(\mathrm{d})$ The plot of the relative emission intensity $\left(I / I_{0}\right)$ versus the composition of the toluene mixture of $T \mathrm{TPy}-\mathrm{H}_{2} \mathrm{O}_{2}$; (e) The plot of fluorescence intensity at 590 $\mathrm{nm}$ of $\mathrm{TPy}-\mathrm{H}_{2} \mathrm{O}_{2}(10 \mu \mathrm{M})$ in DMSO/PBS buffer $(3: 7 \mathrm{v} / \mathrm{v})$ with different $\mathrm{pH}$ values; (f) The selectivity of $T \mathrm{TPy}-\mathrm{H}_{2} \mathrm{O}_{2}$ responses to various analysts. (1: Blank, 2: $\mathrm{ClO}^{-}, 3: \mathrm{O}_{2}^{-}$, 4: TBHP, 5: $\mathrm{OH}, 6: \mathrm{H}_{2} \mathrm{O}_{2}$, 7: NO, 8: Cys, 9: GSH, 10: Vc, 11: Glu, 12: Arg, 13: $\mathrm{Fe}^{3+}$, 14: $\mathrm{Ca}^{2+}$, 15: $\mathrm{Mg}^{2+}$ ); (g) PL intensity and (h) the plot of peak intensity at $590 \mathrm{~nm}$ of $T \mathrm{TPy}-\mathrm{H}_{2} \mathrm{O}_{2}(10 \mu \mathrm{M})$ in response to $\mathrm{H}_{2} \mathrm{O}_{2}(100 \mu \mathrm{M})$ at different time points; (i) $\mathrm{PL}$ intensity of $T \mathrm{PPy}$ $\mathrm{H}_{2} \mathrm{O}_{2}(10 \mu \mathrm{M})$ in response to $\mathrm{H}_{2} \mathrm{O}_{2}$ with different concentrations $(0-160 \mu \mathrm{M})$; (j) The plot of peak intensity at $590 \mathrm{~nm}$ of $T \mathrm{TPy}-\mathrm{H}_{2} \mathrm{O}_{2} \quad(10 \mu \mathrm{M})$ in response to $\mathrm{H}_{2} \mathrm{O}_{2}$ with different concentrations. Inset: Linear plot of peak intensity against $\mathrm{H}_{2} \mathrm{O}_{2}$ concentration $(0-30 \mu M)$; (k) Total ROS generation of $\mathrm{TTP}-\mathrm{H}_{2} \mathrm{O}_{2}$ and TTPy upon white light irradiation using DCFH as indicator; (I) Singlet oxygen generation of TTPy $-\mathrm{H}_{2} \mathrm{O}_{2}$ and TTPy upon white light irradiation using $\mathrm{ABDA}$ as indicator. 

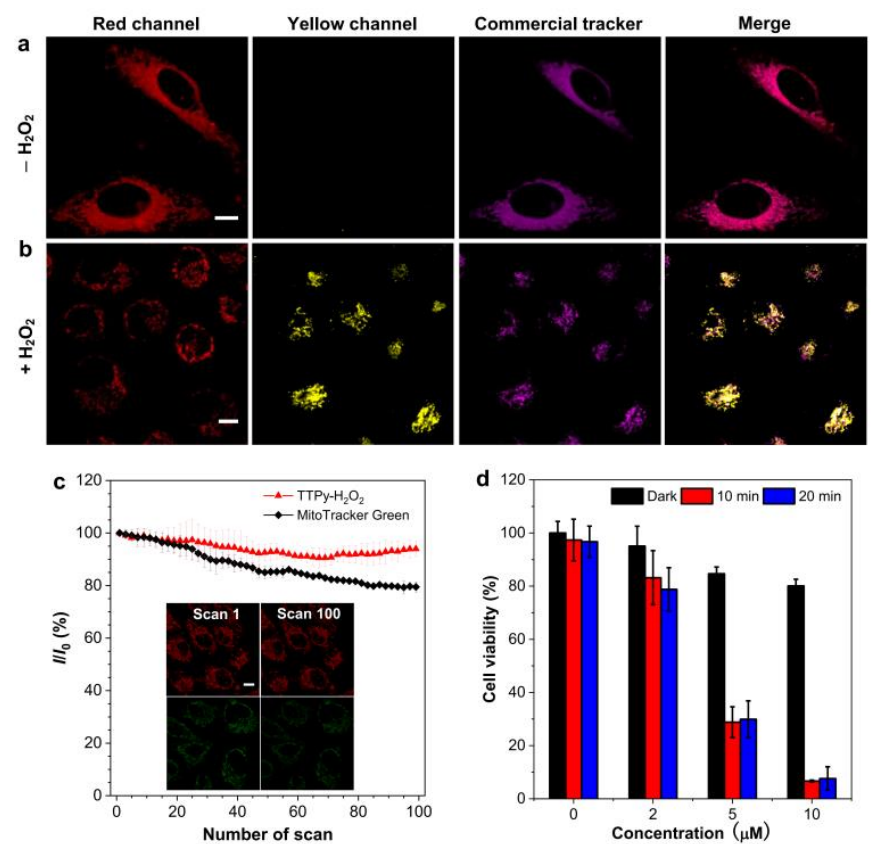

Figure 2. The organelle colocalization and optical properties of $T \mathrm{TPy}-\mathrm{H}_{2} \mathrm{O}_{2}$ before and after the response of $\mathrm{H}_{2} \mathrm{O}_{2}$ in $\mathrm{HeLa}$ cells. (a) Confocal colocalization imaging of $\pi \mathrm{Py}-\mathrm{H}_{2} \mathrm{O}_{2}(5 \mu \mathrm{M})$ with commercial MitoTracker Deep Red $(2 \mu \mathrm{M})$ incubated without $\mathrm{H}_{2} \mathrm{O}_{2}$; (b) Confocal colocalization imaging of $T \mathrm{PPy}-\mathrm{H}_{2} \mathrm{O}_{2} \quad(5 \mu \mathrm{M})$ after incubation with $\mathrm{H}_{2} \mathrm{O}_{2}(50 \mu \mathrm{M})$ for 1 hour, then the cells were stained with commercial lipid droplet (LD) Tracker Deep Red $(2 \mu \mathrm{M})$. Red channel: $\lambda_{\mathrm{ex}}=488 \mathrm{~nm}, \lambda_{\mathrm{em}}=650-700 \mathrm{~nm}$; Yellow channel: $\lambda_{\mathrm{ex}}=405 \mathrm{~nm}, \lambda_{\mathrm{em}}=410-550 \mathrm{~nm}$; Commercial tracker channel: $\lambda_{\mathrm{ex}}=640 \mathrm{~nm}, \lambda_{\mathrm{em}}=650-700 \mathrm{~nm}$. (c) Photostability of $T \mathrm{PPy}-\mathrm{H}_{2} \mathrm{O}_{2}$ and MitoTracker Green. $\lambda_{\mathrm{ex}}=488 \mathrm{~nm}$; Laser power $=0.6 \%$. (d) Cell viability stained with different concentrations of $T \mathrm{TPy}-\mathrm{H}_{2} \mathrm{O}_{2}$ in the absence or presence of white light irradiation. Scale bar: $10 \mu \mathrm{m}$.

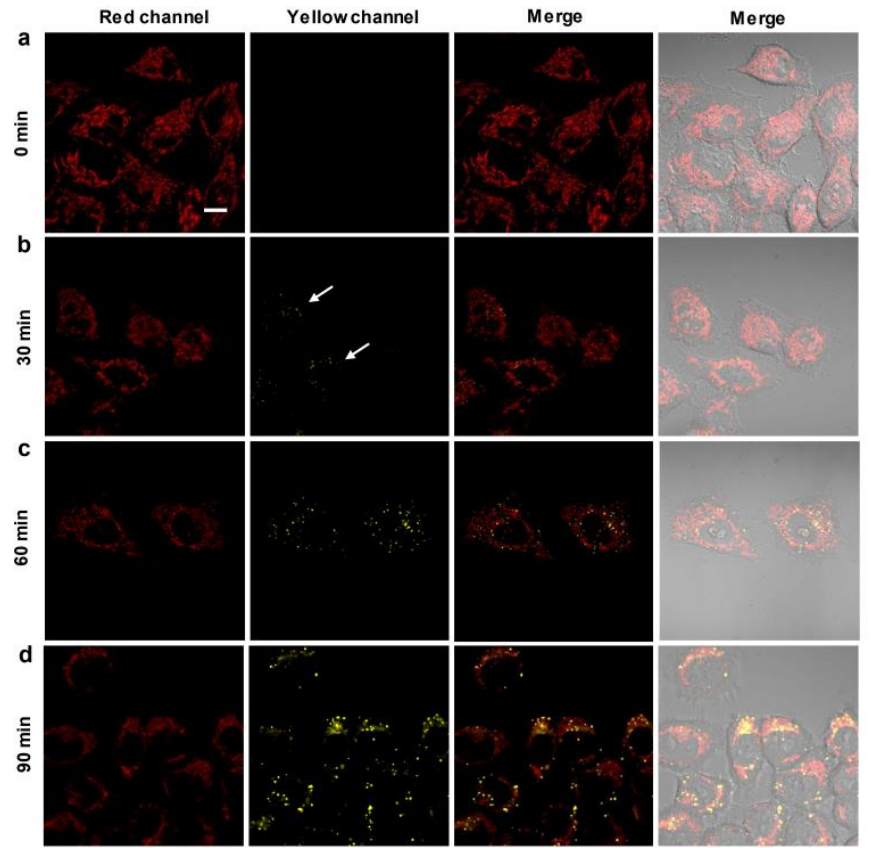

Figure 3. Confocal fluorescence imaging of TTPy $-\mathrm{H}_{2} \mathrm{O}_{2}$ incubated with $\mathrm{H}_{2} \mathrm{O}_{2}(50 \mu \mathrm{M})$ at different time points in HeLa cells. (a) $0 \mathrm{~min}$; (b) $30 \mathrm{~min}$; (c) $60 \mathrm{~min}$ and (d) $90 \mathrm{~min}$ (white arrows highlighted LD with yellow florescence). Red channel: $\lambda_{\mathrm{ex}}=488 \mathrm{~nm}, \lambda_{\mathrm{em}}=650-700 \mathrm{~nm}$; Yellow channel: $\lambda_{\mathrm{ex}}=405 \mathrm{~nm}, \lambda_{\mathrm{em}}=$ 410-550 nm; Scale bar: $10 \mu \mathrm{m}$. 


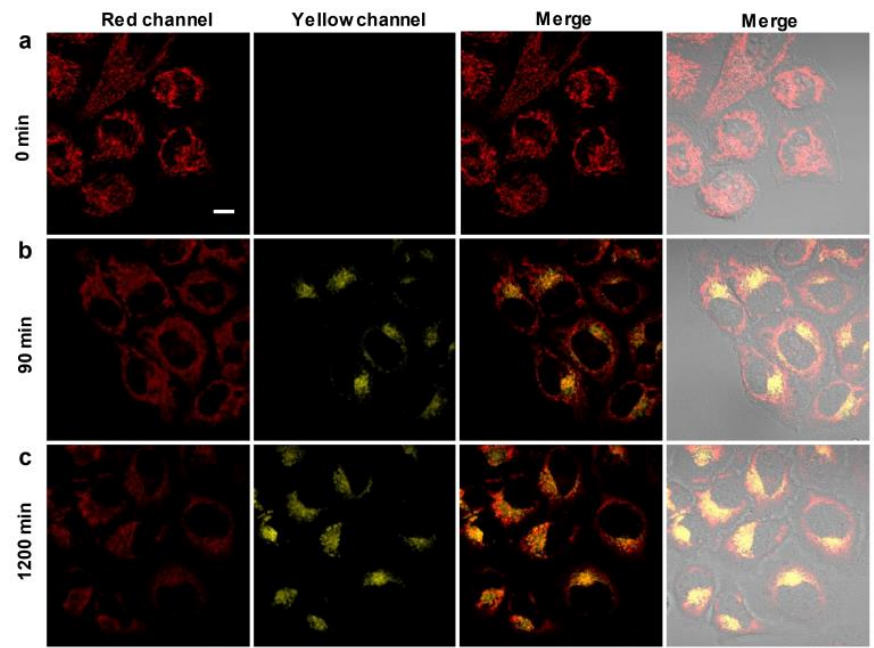

Figure 4. Confocal fluorescence imaging of $\mathrm{HeLa}$ cells incubated with $\mathrm{TPP}-\mathrm{H}_{2} \mathrm{O}_{2}$ for $30 \mathrm{~min}$, followed by the incubation with $\mathrm{PMA}(2 \mu \mathrm{g} / \mathrm{mL}$ ) to produce more endogenous $\mathrm{H}_{2} \mathrm{O}_{2}$ at different time points. (a) $0 \mathrm{~min}$; (b) $90 \mathrm{~min}$; (c) $120 \mathrm{~min}$. Red channel: $\lambda_{\mathrm{ex}}=488 \mathrm{~nm}, \lambda_{\mathrm{em}}=650-700 \mathrm{~nm}$; Yellow channel: $\lambda_{\mathrm{ex}}=405$ $\mathrm{nm}, \lambda_{\mathrm{em}}=410-550 \mathrm{~nm}$; Scale bar: $10 \mu \mathrm{m}$

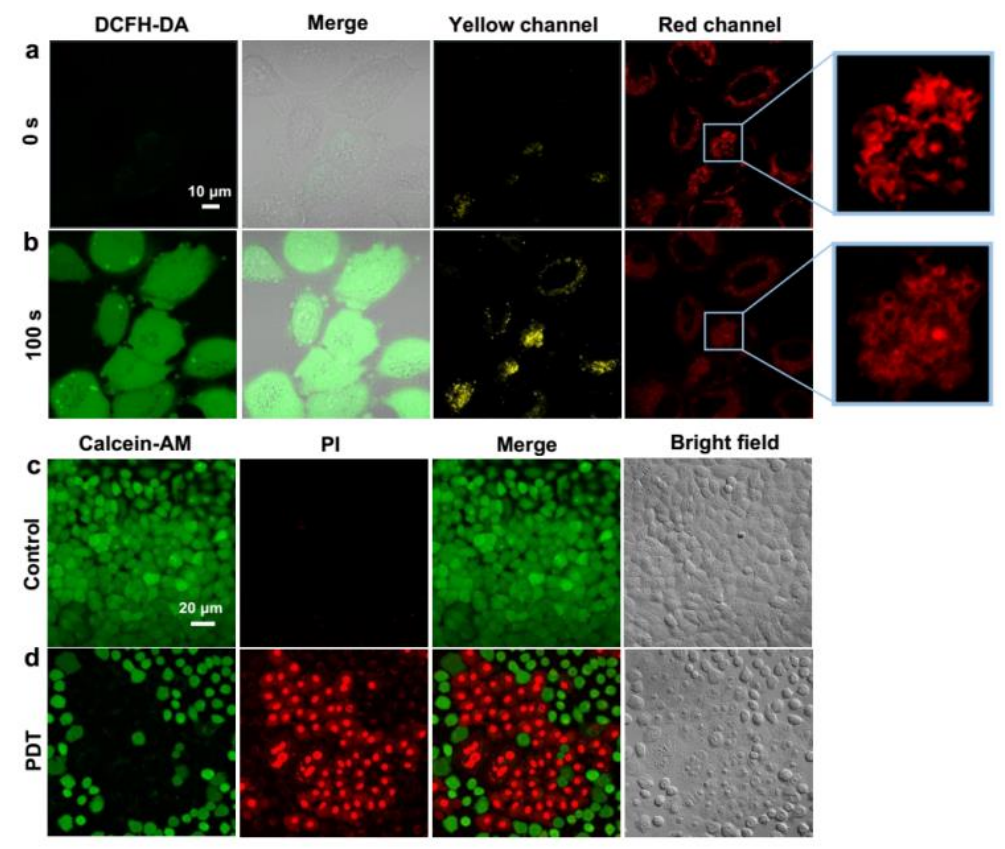

Figure 5. Confocal fluorescence imaging of photodynamic therapy of HeLa cells. (a, b) Intracellular ROS level after incubated with $\mathrm{TTPy}-\mathrm{H}_{2} \mathrm{O}_{2}$ for 30 min, followed by the staining with DCFH-DA (10 $\mu$ M) upon 488nm laser irradiation. Red channel: $\lambda_{\mathrm{ex}}=488 \mathrm{~nm}, \lambda_{\mathrm{em}}=650-700 \mathrm{~nm}$; Yellow channel: $\lambda_{\mathrm{ex}}=405 \mathrm{~nm}$, $\lambda_{\mathrm{em}}=410-550 \mathrm{~nm}$; Scale bar: $10 \mu \mathrm{m}$. (c and d) Live/dead cell staining of Calcein-AM/PI after white light irradiation $\left(16 \mathrm{~mW} / \mathrm{cm}^{2}\right)$ for $20 \mathrm{~min} . \mathrm{Scale}$ bar: 20 $\mu \mathrm{m}$. 